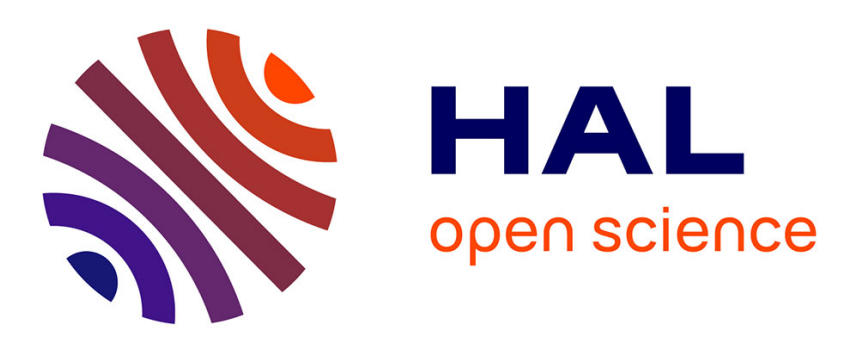

\title{
Influence of cambial age and climate on ring width and wood density in Pinus radiata families
}

Miloš Ivković, Washington Gapare, Harry Wu, Sergio Espinoza, Philippe Rozenberg

\section{- To cite this version:}

Miloš Ivković, Washington Gapare, Harry Wu, Sergio Espinoza, Philippe Rozenberg. Influence of cambial age and climate on ring width and wood density in Pinus radiata families. Annals of Forest Science, 2013, 70 (5), pp.525-534. 10.1007/s13595-013-0290-z . hal-01201497

\section{HAL Id: hal-01201497 \\ https://hal.science/hal-01201497}

Submitted on 17 Sep 2015

HAL is a multi-disciplinary open access archive for the deposit and dissemination of scientific research documents, whether they are published or not. The documents may come from teaching and research institutions in France or abroad, or from public or private research centers.
L'archive ouverte pluridisciplinaire HAL, est destinée au dépôt et à la diffusion de documents scientifiques de niveau recherche, publiés ou non, émanant des établissements d'enseignement et de recherche français ou étrangers, des laboratoires publics ou privés. 


\title{
Influence of cambial age and climate on ring width and wood density in Pinus radiata families
}

\author{
Miloš Ivković • Washington Gapare • Harry Wu • \\ Sergio Espinoza $\cdot$ Philippe Rozenberg
}

Received: 19 September 2012 /Accepted: 10 April 2013 /Published online: 2 May 2013

(C) INRA and Springer-Verlag France 2013

\begin{abstract}
- Context The correlation between tree ring width and density and short-term climate fluctuations may be a useful tool for predicting response of wood formation process to longterm climate change.

- Aims This study examined these correlations for different radiata pine genotypes and aimed at detecting potential genotype by climate interactions.

- Methods Four data sets comprising ring width and density of half- and full-sib radiata pine families were used. Correlations with climate variables were examined, after the extraction of the effect of cambial age.

- Results Cambial age explained the highest proportion of the ring to ring variation in all variables. Calendar year and year by family interaction explained a smaller but significant proportion of the variation. Rainfall had a positive correlation with ring width and, depending on test site,
\end{abstract}

Handling Editor: Gilbert Aussenac

Contribution of co-authors Dr. Gapare contributed data and ideas, and reviewed the final manuscript.

$\mathrm{Dr} \mathrm{Wu}$ organised the sampling of field trials, contributed data and reviewed the final manuscript.

Mr Espinoza contributed ideas and commented on methodology and earlier drafts of the manuscript.

Dr Rozenberg contributed to data analyses (R functions) and ideas that initiated this work.

M. Ivković $(\bowtie) \cdot$ W. Gapare $\cdot$ H. Wu

Plant Industry, Commonwealth Scientific

and Industry Research Organisation, GPO Box 1600,

Canberra, ACT 2601, Australia

e-mail: Milosh.Ivkovich@csiro.au

\section{S. Espinoza}

Dryland Technological Center, The Catholic University of Maule,

Talca, Chile

P. Rozenberg

Unité de Recherche Amélioration, Génétique et Physiologie

Forestières, INRA, Orléans, France either a negative or positive correlation with ring density. Correlations between temperature during growing season and ring density were generally negative.

- Conclusion Climate variables that influence ring width and wood density can be identified from ring profiles, after removing the cambial age effect. Families can be selected that consistently show desirable response to climate features expected to become prevalent as a result of climate change.

Keywords Radiata pine - Adaptation · Climate change · Tree rings $\cdot$ Earlywood $\cdot$ Latewood

\section{Introduction}

The paper attempts to answer certain questions important for our understanding of how trees respond to the climate in which they grow. In temperate climates, there is a strong variation in photoperiod, temperature and balance between water demand and availability, during any given year and between different years. This variability is reflected in wood characteristics, and consequently, most of the variation in wood properties resides within and between growth rings (Ivković and Rozenberg 2004; Downes et al. 2009; Guller et al. 2012). Studies of wood are important to knowledge of tree plasticity and adaptation to climate because tree rings provide a retrospective record of the environmental influences on wood formation process (e.g. Martinez-Meier et al. 2009).

The record of wood response to short-term climate changes (e.g. wood density profile) can be used to predict the future response of wood to long-term climate fluctuations caused by climate change (Chen et al. 2010; McLane et al. 2011). Although the response may be different for different climate regimes, planting sites or sets of genotypes, such response is highly indicative of changes in wood structure due to temporal changes in climate conditions 
(e.g. Fritts 1976). Knowledge of pedigree of trees improves significantly the predictive power of statistical models of the response (Rozenberg et al. 2001).

For radiata pine (Pinus radiata D. Don.) grown in southern Australia, climate variables such temperature and rainfall vary significantly from 1 year to another causing differences in growth and wood density over years (CSIRO 2001; Li and $\mathrm{Wu} 2005$ ). If an interaction of genotypes (i.e. half- or full-sib families) with climate variables during certain years is detected, that may have implications for interactions with future climate change. For example, a genotype that does not respond favourably to drought periods may be eliminated from the breeding programme (e.g. Martinez-Meier et al. 2008).

However, in juvenile radiata pine trees (in first 8 to 13 rings), there is a strong trend in ring width and wood properties from corewood to outerwood, which is related to cambial age (e.g. Gapare et al. 2006, 2012). Progeny trials usually consist of young trees, and for information from such trials to be useful in studies of climate effects and genotype by climate interaction, the effect of cambial age needs to be removed. Using dendro-chronological terminology, the data need to be standardised prior to further analyses (Fritts 1976). One the other hand, if dealing with adult (e.g. $>15$ years) trees, transition to outer (or mature) wood zone could be determined so that the analyses can be done on the rings in the outerwood zone, where the effect of cambial age is diminished (Gapare et al. 2006; Guller et al. 2012).

\subsection{Objectives}

This study investigated primarily genotype-by-cambial age and genotype-by-calendar year interaction for wood properties. This paper attempts to provide answers to the following questions:

1. Are there significant interactions between genetic and cambial age effects on ring width and/or ring density?

2. What climate variables significantly affect ring width and wood density, two traits which are determining productivity and wood quality of radiata pine?

3. Is there a genotype-by-calendar year interaction for ring width and wood density, and what climate variables cause the interaction?

4. Can we draw some conclusions in terms of tree productivity and wood quality, based on the effects of year to year climate fluctuations, which would have implications for genetic selection in face of climate change?

\section{Materials and methodology}

To study genotype-by-cambial age and genotype-bycalendar year interactions for ring width and wood density, we compiled data obtained from breast height wood samples from four progeny trials.

\subsection{Trials at rotation age}

Two progeny trials were sampled at rotation age (i.e. age $>27$ years) in two major Australian radiata pine production regions. The trial in Gippsland, Victoria (PT1) was harvested in 2000 at age 31 years after planting, and the trial in Green Triangle, South Australia (PT2) was harvested in 1998 at age 27 years after planting. A total of 1,097 breast height $(1.3 \mathrm{~m})$ cross-section disks collected at the two sites were used for the analyses. The two trials shared the same 30 open-pollinated families, and on average 36.5 trees were sampled per family. Only trees that were not suppressed (i.e. dominant and codominant) were selected for sampling. Further details of location, soil type and climate for the two trials are given in Table 1 and in Li and $\mathrm{Wu}$ (2005) and Gapare et al. (2006).

\subsection{Trials at mid-rotation}

Two 16-year-old progeny trials PT 3 and PT4 were sampled in the Gippsland region, Victoria. They comprised families from seven sets of $6 \times 6$ half diallels. At PT3 site, wood disks at breast height were collected from 100 full-sib families involving 42 parents with an average of four crosses per parent (of which 13 were controls). At PT4 site, 52 full-sib families involving 31 parents with an average of three crosses per parent were sampled. There were differences in previous land use between the two sites: ex-pasture sites are usually more fertile than second rotation sites. Further details of trial characteristics are given in the Table 1 and Gapare et al. (2006).

\subsection{Sample preparation and wood density measurement}

Two radial strips from each disk were cut using a twin-blade circular saw, one strip from south of the pith and the second from north of the pith. The strips were approximately 10 $12 \mathrm{~mm}$ wide on the transverse surface and $2.2 \mathrm{~mm}$ thick. The strips were extracted with laboratory-grade acetone, and gravimetric density was measured using the water displacement method before X-ray scanning. The samples were scanned indirectly (i.e. X-ray film scanning), to determine the basic wood density (oven-dry weight/saturated volume in grams per cubic centimetre) for each ring from pith to bark. Correlation between density obtained from X-rayed subsamples with density determined by direct scanning densitometry by SilviScan ${ }^{\circledR}$ (Evans and Ilic 2001) was high $\left(R^{2}=0.94\right)$.

Annual growth ring width (RW), density (RD), latewood density (LWD) and earlywood density (EWD) were measured on an X-ray film using the WinDendro measurement software (Regent Instruments Inc. 2001). A total of 28 annual rings were analysed on disks from the 
Table 1 Site characteristics, trial design and sample size for the four trials used in this study (adapted from Gapare et al. 2006)

\begin{tabular}{|c|c|c|c|c|}
\hline Progeny trial & PT1 & PT2 & PT3 & PT4 \\
\hline Year planted & 1969 & 1971 & 1986 & 1986 \\
\hline Age harvested (years) & 31 & 27 & 16 & 16 \\
\hline Latitude & $38^{\circ} 12^{\prime} \mathrm{S}$ & $37^{\circ} 29^{\prime} \mathrm{S}$ & $38^{\circ} 14^{\prime} \mathrm{S}$ & $38^{\circ} 15^{\prime} \mathrm{S}$ \\
\hline Longitude & $146^{\circ} 40^{\prime} \mathrm{E}$ & $140^{\circ} 40^{\prime} \mathrm{E}$ & $146^{\circ} 41^{\prime} \mathrm{E}$ & $146^{\circ} 39^{\prime} \mathrm{E}$ \\
\hline Elevation (m) & 100 & 62 & 93 & 184 \\
\hline Annual rainfall (mm) & 760 & 900 & 760 & 785 \\
\hline Soil type & Sandy loam & Sandy clay loam & Sandy loam & Sandy loam \\
\hline Site type & Ex-pasture & 2nd PR & Ex-pasture & 2nd PR \\
\hline Family structure & Half-sib & Half-sib & Full-sib & Full-sib \\
\hline No. of families & 36 & 33 & 100 & 52 \\
\hline No. of trees/family & 18 & 27 & 6 & 6 \\
\hline No. of blocks & 9 & 6 & 3 & 6 \\
\hline Plot type & $2 \times 3$ & 10 tree rows & 4 tree rows & single tree \\
\hline Total trees & 648 & 780 & 600 & 312 \\
\hline
\end{tabular}

2nd $P R$ second rotation of radiata pine crop

PT1, 26 rings were analysed for the PT2 and 16 rings were analysed for both PT3 and PT4. The first and last annual rings of each sample were rejected because they were incomplete. For each annual ring, earlywood and latewood boundary was delineated, using the $50 \%$ difference between maximum and minimum ring density as threshold.

\subsection{Climate data}

The trials PT1, PT2 and PT3 in Gippsland, Victoria had temperate climate, while trial PT2 in the Green Triangle region, South Australia had Mediterranean climate type. The weather station in closest to the progeny trials PT1, PT3 and PT4 was in Callignee North (latitude $38.3^{\circ} \mathrm{S}$, longitude $146.6^{\circ} \mathrm{E}$ and elevation $184 \mathrm{~m}$ ), with observations of rainfall and temperature. Weather stations closest to the progeny trial PT2 were: Tantanoola (latitude $37.7^{\circ} \mathrm{S}$, longitude $140.5^{\circ} \mathrm{E}$ and elevation $25 \mathrm{~m}$ ), with observations for rainfall, and at Mt. Gambier Airport (latitude $37.7^{\circ} \mathrm{S}$, longitude $140.8^{\circ} \mathrm{E}$ and elevation $63 \mathrm{~m}$ ), with observations for temperature. The climate variables obtained included rainfall and temperature. The averages were calculated as annual, growing season (September to March) and summer (December to February). The variables were: rainfall annual, growing season and summer; mean temperature annual, growing season and in summer, maximum temperature summer and the De Martonne's (1926) moisture index (i.e. total rainfall/(mean temperature+10)) (DMI). An advantage of DMI was that it was simple to compute for either whole year, growing season or summer periods (Table 2).

\subsection{Statistical analyses}

A mixed linear model was fitted to tree ring variables (i.e., RW, RD, LWD and EWD) in order to determine which factors (i.e. cambial age, year, family, family by cambial age and family by year) explain most of their annual variability. The model had the following terms:

$$
\begin{aligned}
Y_{i j k l}= & \mathrm{CA}_{\mathrm{i}}+\operatorname{spl}\left(\mathrm{CA}_{i}\right)+F_{j}+Y_{k} \\
& +\operatorname{spl}\left(\mathrm{CA} \times F_{i j}\right)+Y \times F_{k j}+\mathrm{e}_{(i j k) l}
\end{aligned}
$$

where $Y_{i j k l}$ is the observed response for cambial age $i$, in year $k$, in family $j$ and tree $l ; \mathrm{CA}_{i}$ is the fixed effect of cambial age $i ; \operatorname{spl}\left(\mathrm{CA}_{i}\right)$ is the random cambial age trend approximated by a cubic spline (Apiolaza and Garrick 2001; Apiolaza 2009; Butler et al. 2009); $F_{j}$ is the random family effect; $Y_{k}$ is the random effect of year (i.e. calendar year) or the non-smooth variation over time; $\times$ is denoting an interaction between two terms; and $e_{(i j k) l}$ is the unexplained residual variation.

Of primary interest was the interaction $Y \times F$ between year and family effects. The effect of cambial age random regression spl(CA) was included not only to remove the age trend from the effect of primary interest, but also to find out whether the cambial age trend varies among families. Genetic differences were evaluated by testing whether the interaction term $\mathrm{spl}(\mathrm{CA} \times F)$ significantly improves the model by performing likelihood ratio tests.

The cubic spline is a flexible, smooth curve that can be used for removing trends with no mathematical assumptions on the shape of the trend (Harrell 2001). The implementation of cubic smoothing splines in ASReml-R is based on the mixed model formulation of Verbyla et al. (1999). The 
Table 2 Climate data averages 1971-1999 for PT1; 1972-1997 for PT2; 1987-2001 for PT3; and 1987-2002 for PT4

\begin{tabular}{|c|c|c|c|c|c|c|c|c|c|c|}
\hline & R_A (mm) & R_GS (mm) & R_S (mm) & MT_A $\left({ }^{\circ} \mathrm{C}\right)$ & MT_GS $\left({ }^{\circ} \mathrm{C}\right)$ & MT_S $\left({ }^{\circ} \mathrm{C}\right)$ & MaxT_GS $\left({ }^{\circ} \mathrm{C}\right)$ & MaxT_S $\left({ }^{\circ} \mathrm{C}\right)$ & DMI & DMI_GS \\
\hline PT1 & 832 & 390 & 156 & 14 & 16 & 19 & 22 & 25 & 30 & 22 \\
\hline PT2 & 786 & 270 & 96 & 14 & 16 & 18 & 22 & 24 & 33 & 21 \\
\hline PT3 and PT4 & 845 & 414 & 171 & 14 & 16 & 19 & 21 & 24 & 32 & 24 \\
\hline
\end{tabular}

$R \_A$ rainfall annual, $R \_G S$ growing season, $R \_S$ summer, $M T \_A$ mean temperature annual, $M T \_G S$ growing season, $M T \_S$ growing season summer, $\overline{M a x} T \_G S$ maximum temperature growing season, MaxT_S maximum temperature summer, $\bar{D} M I$ GS De Martonne's (1926) moisture index (i.e. total rainfall/(mean temperature+10)) (MI_GS and MI_S)

flexibility of the curve determines how well it fits the data and is controlled by the number of knots $n\left(t_{1}, \ldots, t_{n}\right)$. The parsimony of the model or balance between the fit and the number of parameters (i.e. knots) was examined by using the AIC statistic (ASReml-R 3.0, Butler et al. 2009). For $\mathrm{RD}$, at least six knots, i.e., equally distributed percentiles of the cambial age, were used and for RW eight knots at percentiles of the cambial age were used.

This cubic spline modelled the cambial age trend:

$\operatorname{spl}(\mathrm{CA})=\beta_{0}+\beta_{1} \mathrm{CA}_{1}+\beta_{2} \mathrm{CA}_{2}+\ldots+\beta_{\mathrm{n}-1} \mathrm{CA}_{\mathrm{n}-1}$

where $\mathrm{CA}_{1}=\mathrm{CA}$ the vector of cambial ages, and for knots $m=1, \ldots, n-2$,

$$
\begin{aligned}
\mathrm{CA}_{\mathrm{m}+1}= & \left(\mathrm{CA}-\mathrm{t}_{\mathrm{m}}\right)^{3}+\left(\mathrm{CA}-\mathrm{t}_{\mathrm{n}-1}\right)^{3}+ \\
& +\left(\mathrm{t}_{\mathrm{n}}-\mathrm{t}_{\mathrm{m}}\right) /\left(\mathrm{t}_{\mathrm{n}}-\mathrm{t}_{\mathrm{n}-1}\right)+\left(\mathrm{CA}-\mathrm{t}_{\mathrm{n}}\right)^{3}+ \\
& +\left(\mathrm{t}_{\mathrm{n}-1}-\mathrm{t}_{\mathrm{n}}\right) /\left(\mathrm{t}_{\mathrm{n}}-\mathrm{t}_{\mathrm{n}-1}\right)
\end{aligned}
$$

is the $m$ th $(m=2, \ldots, n-1)$ component of the cubic spline and the segmenting symbol $(u)_{+}=u, u>0$ otherwise $(u)_{+}=0, u \leq 0$ (Harrell 2001).

\subsection{Correlations with climate variables}

There was up to 4 years range in maximum cambial age (at breast height) for a given calendar year, even though the age from seed was the same for all trees. Using cambial instead of tree age made possible to analyse the effect of cambial age independently from that of calendar year. The above statistical model was used to extract the random year effects (i.e. non-smooth variation at overall mean and family levels), in order to study correlation of wood variables with climatic variables. In other words, the series were de-trended by fitting cubic spline curves and then correlated with climate variables. The correlation of calendar year effects with selected climatic variables for current and previous years was then explored using R 2.14 software (R Core Team 2012).

\subsection{Repeated measurement analyses}

In two trials at rotation age PT1 and PT2, the above smoothing spline model was also used to determine the transition from corewood to outerwood, where the effect of cambial age was diminished. Repeated measurement analyses were then used to evaluate differences in RW, RD, LWD and EWD among families and family by year interaction. Family by year interaction effect was obtained from analyses of repeated measures on each experimental unit (i.e. tree), in adult rings for which cambial age effect was not significant (cambial age $>15$ years).

Within-tree errors were considered auto-correlated because the values for adjacent rings tend to be more correlated than in rings several years apart (Apiolaza 2009). This is mainly because physiological processes within a tree create a lag in response to climate, and also because climate anomalies tend to persist from 1 year to the next (e.g. Fritts 1976). The package ASReml-R 3.0 (Butler et al. 2009) provides different structures for within tree variance-covariance matrices, but the most appropriate one, with the property of

\begin{tabular}{|c|c|c|c|c|c|c|c|c|c|c|}
\hline \multirow[b]{2}{*}{ Site } & \multicolumn{2}{|c|}{ Number of rings } & \multicolumn{2}{|l|}{ RW (mm) } & \multicolumn{2}{|l|}{$\mathrm{RD}$} & \multicolumn{2}{|l|}{ LWD } & \multicolumn{2}{|l|}{ EWD } \\
\hline & Mean \pm st.dev & Range & Mean \pm st.dev & Range & Mean \pm st.dev & Range & Mean \pm st.dev & Range & Mean \pm st.dev & Range \\
\hline PT1 & $27.8 \pm 1.0$ & $16-28$ & $4.6 \pm 0.9$ & $2.4-7.6$ & $0.408 \pm 0.049$ & $0.298-0.594$ & $0.600 \pm 0.053$ & $0.447-0.884$ & $0.306 \pm 0.043$ & $0.226-0.413$ \\
\hline PT2 & $26.2 \pm 2.2$ & $12-27$ & $5.0 \pm 1.0$ & $2.3-8.4$ & $0.367 \pm 0.034$ & $0.286-0.522$ & $0.500 \pm 0.050$ & $0.346-0.729$ & $0.267 \pm 0.031$ & $0.191-0.420$ \\
\hline PT3 & $15.0 \pm 0.2$ & $12-15$ & $6.9 \pm 0.8$ & $3.8-9.5$ & $0.342 \pm 0.033$ & $0.262-0.433$ & $0.430 \pm 0.040$ & $0.324-0.515$ & $0.302 \pm 0.028$ & $0.245-0.381$ \\
\hline PT4 & $15.9 \pm 0.2$ & $12-16$ & $7.2 \pm 1.1$ & $3.6-10.6$ & $0.367 \pm 0.033$ & $0.298-0.437$ & $0.473 \pm 0.038$ & $0.385-0.550$ & $0.315 \pm 0.027$ & $0.260-0.370$ \\
\hline
\end{tabular}

Table 3 Mean and (among tree) standard deviation and range of number of rings, ring width, ring relative density, latewood density and earlywood density for four test sites

st.dev standard deviation, $R W$ ring width, $R D$ ring relative density, $L W D$ latewood density, $E W D$ earlywood density 
Fig. 1 Profiles of ring width $(R W)$, relative ring density $(R D)$ and latewood $(L W D)$ and earlywood $(E W D)$ density development over cambial ages in four progeny trials
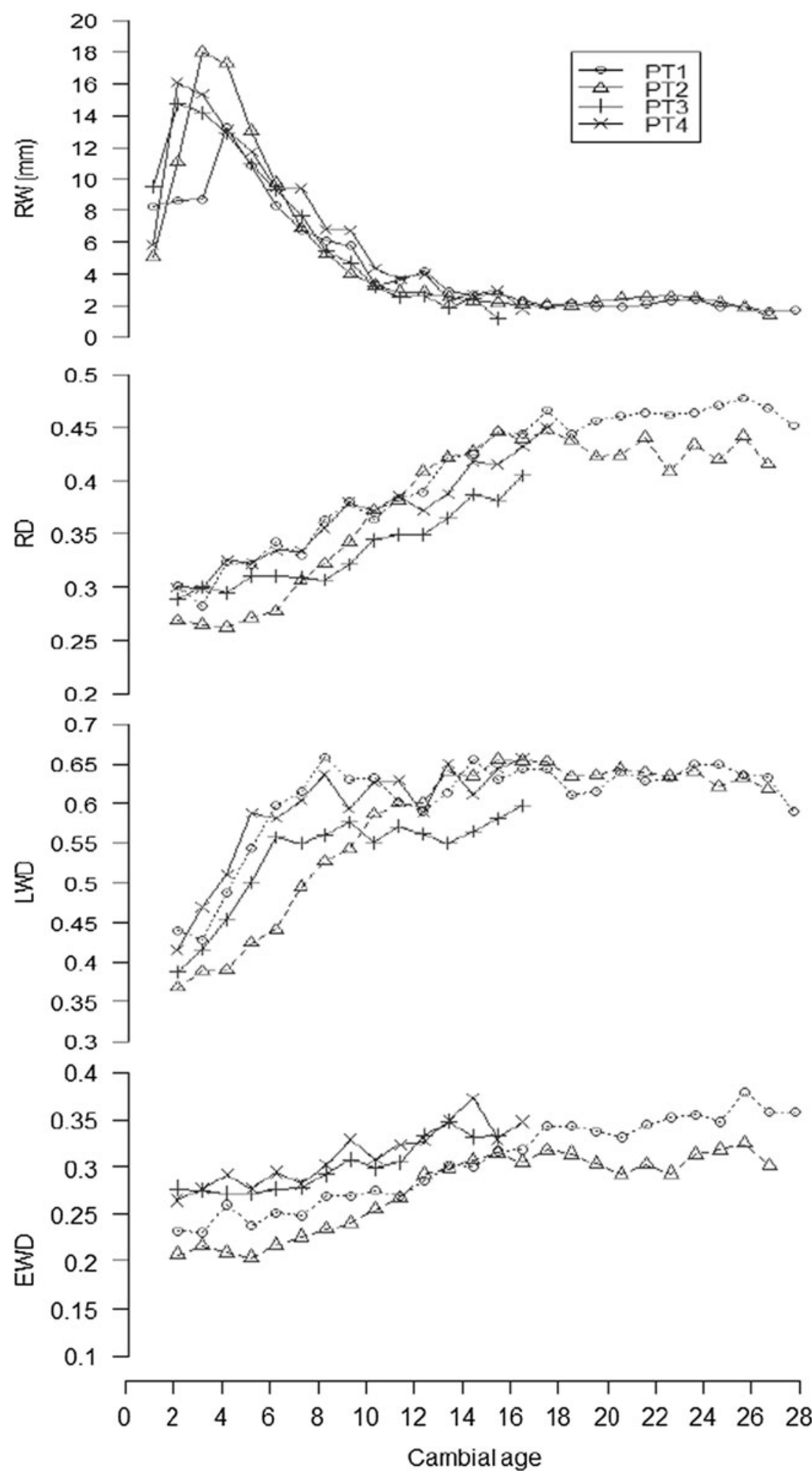

correlation being larger for nearby rings than for those far apart, is first-order auto-regressive AR1 (Littell et al. 1996). The $Y \times F$ interaction was explored by calculating the average number of rank changes for families over years by using software R 2.14 (R Core Team 2012).

\section{Results}

The basic statistics for $P$. radiata ring width and wood density at four sites are given in Table 3 . Profiles of average RW, RD, LWD and EWD over cambial age at four sites are 
Table 4 Variance component to error variance ratios for main effects of cambial age spline and year and for interaction terms cambial age spline by family for variables: ring width and ring density, latewood density and earlywood density

\begin{tabular}{llllll}
\hline & & RW & RD & LWD & EWD \\
\hline PT1 & $\operatorname{spl}(\mathrm{CA})$ & $14.01^{*}$ & $0.114 \mathrm{~ns}$ & $2.41 \mathrm{~ns}$ & $0.000 \mathrm{~ns}$ \\
& $Y$ & $0.316^{* * *}$ & $0.043^{* *}$ & $0.077^{* *}$ & $0.033^{* *}$ \\
& $\operatorname{spl}(\mathrm{CA}) \times F$ & $0.013^{* * *}$ & $0.002^{*}$ & $0.003^{*}$ & $0.000 \mathrm{~ns}$ \\
PT2 & $\operatorname{spl}(\mathrm{CA})$ & $4.670^{*}$ & $1.604^{*}$ & $0.235 \mathrm{~ns}$ & $0.235 \mathrm{~ns}$ \\
& $Y$ & $0.726^{* * *}$ & $0.084^{* * *}$ & $0.026^{* *}$ & $0.026^{* *}$ \\
& $\operatorname{spl}(\mathrm{CA}) \times F$ & $0.020^{* * *}$ & $0.008^{* * *}$ & $0.005^{* * *}$ & $0.005^{* * *}$ \\
PT3 & $\operatorname{spl}(\mathrm{CA})$ & $21.58^{*}$ & $9.25^{*}$ & $0.394 \mathrm{~ns}$ & $1.94 \mathrm{~ns}$ \\
& $Y$ & $1.156^{*}$ & $0.479^{*}$ & $0.062^{*}$ & $0.106^{*}$ \\
& $\operatorname{spl}(\mathrm{CA}) \times F$ & $0.054^{* * *}$ & $0.002 \mathrm{~ns}$ & $0.004 \mathrm{~ns}$ & $0.004^{* *}$ \\
PT4 & $\operatorname{spl}(\mathrm{CA})$ & $26.68 \mathrm{~ns}$ & $0.82 \mathrm{~ns}$ & $1.012 \mathrm{~ns}$ & $7.069 \mathrm{~ns}$ \\
& $Y$ & $1.30^{*}$ & $0.094^{*}$ & $0.203^{* *}$ & $0.576^{*}$ \\
& $\operatorname{spl}(\mathrm{CA}) \times F$ & $0.053^{* * *}$ & $0.34^{* * *}$ & $0.006^{* *}$ & $0.003^{*}$ \\
\hline
\end{tabular}

spl(CA) cambial age spline, $Y$ year $(Y),(\operatorname{spl}(C A) \times F)$ cambial age spline by family, $R W$ ring width, $R D$ ring density, $L W D$ latewood density, $E W D$ earlywood density, $n s$ not significantly different from 0 ${ }^{* * *} p=0.001$, significantly different from $0 ;{ }^{* *} p=0.01$, significantly different from $0 ;{ }^{*} p=0.05$, significantly different from 0
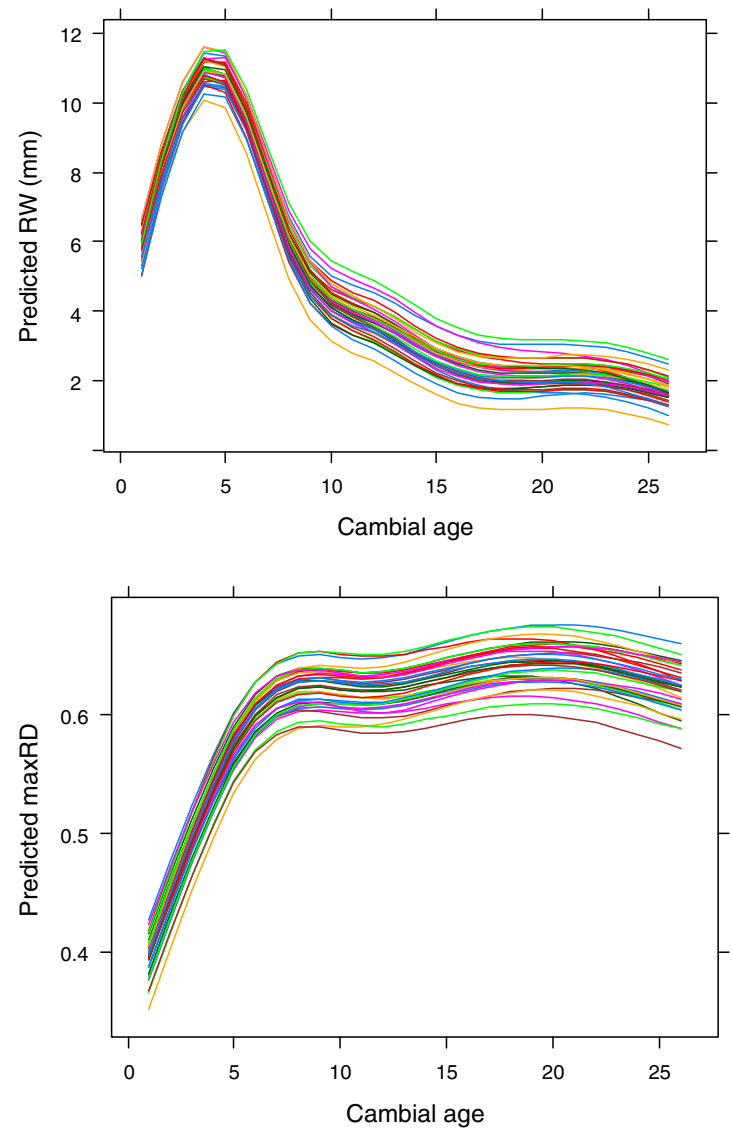

presented in Fig. 1. After an initial increase in RW, a strong decrease was evident regardless of site, but the rate of decrease differed between sites. In PT1 and PT2, contrasting patterns were observed for RD and EWD, vs. LWD. The increase over cambial age of RD and EWD was slower and took longer ( $>15$ years) to stabilise, while LWD increased sharply during the first 5-7 years and then stabilised. The ex-pasture site PT3 showed lower RD and LWD than second rotation pine site PT4. It was also clear that trees from PT3 and PT4 were more or less still in the juvenile phase.

The annual development of ring width and density was best explained by a linear mixed model with the explanatory variables: cambial age trend $(\operatorname{spl}(\mathrm{CA}))$, calendar year $(Y)$, the interaction $\operatorname{spl}(\mathrm{CA}) \times Y$ and random interaction $\mathrm{spl}(\mathrm{CA}) \times$ $F$. It was clear that the $\mathrm{spl}(\mathrm{CA})$ explained the highest proportion of the variation (i.e. gamma estimate) in ring width and ring density over cambial ages; however, the error on the estimate was also high. On the other hand, the year main effect $(Y)$ explained only a minor, but statistically significant proportion of variation (Table 4).

The fitted cubic spline models of RW, RD, LWD and EWD for all families at a progeny trial PT2 are presented in Fig. 2. For those traits, PT1 showed similar juvenile to
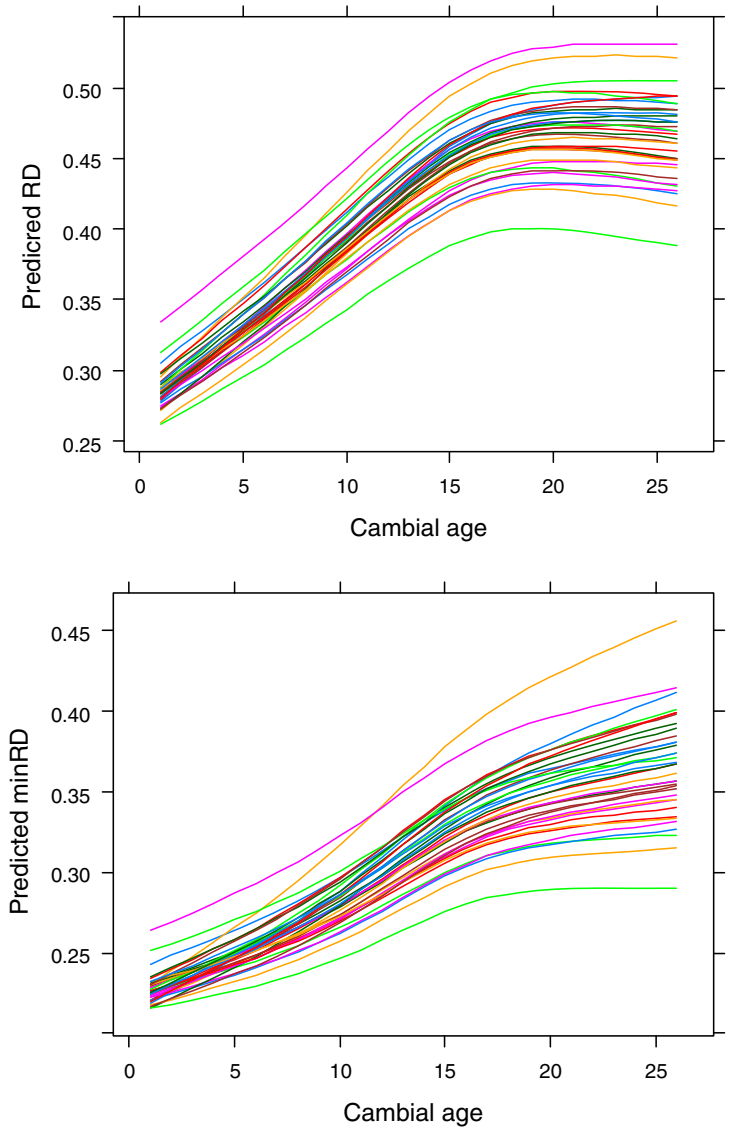

Fig. 2 Predicted values (cubic splines) of ring width $(R W)$, relative ring $(R D)$ and latewood $(L W D)$ and earlywood $(E W D)$ density over cambial age for 33 half-sib families at PT2 
Table 5 Correlations between current year effects on ring width, latewood, earlywood and average density and climate variables for PT1 and PT2, between 1974 and 1997

\begin{tabular}{|c|c|c|c|c|c|c|c|c|c|}
\hline & & R_A (mm) & R_GS (mm) & R_S (mm) & MT_A $\left({ }^{\circ} \mathrm{C}\right)$ & MT_GS $\left({ }^{\circ} \mathrm{C}\right)$ & MT_S $\left({ }^{\circ} \mathrm{C}\right)$ & MaxT_S $\left({ }^{\circ} \mathrm{C}\right)$ & DMI_GS \\
\hline \multirow[t]{4}{*}{ PT1 } & RW & $0.38^{*}$ & $0.00 \mathrm{~ns}$ & $0.23 \mathrm{~ns}$ & $0.01 \mathrm{~ns}$ & $-0.37^{*}$ & $-0.27 \mathrm{~ns}$ & $-0.17 \mathrm{~ns}$ & $0.38^{*}$ \\
\hline & $\mathrm{RD}$ & $-0.07 \mathrm{~ns}$ & $0.07 \mathrm{~ns}$ & $-0.10 \mathrm{~ns}$ & $-0.30 \mathrm{~ns}$ & $-0.01 \mathrm{~ns}$ & $-0.10 \mathrm{~ns}$ & $-0.12 \mathrm{~ns}$ & $-0.05 \mathrm{~ns}$ \\
\hline & LWD & $0.18 \mathrm{~ns}$ & $-0.10 \mathrm{~ns}$ & $-0.20 \mathrm{~ns}$ & $-0.36^{*}$ & $-0.30 \mathrm{~ns}$ & $-0.28 \mathrm{~ns}$ & $-0.27 \mathrm{~ns}$ & $0.21 \mathrm{~ns}$ \\
\hline & EWD & $-0.05 \mathrm{~ns}$ & $-0.30 \mathrm{~ns}$ & $-0.26 \mathrm{~ns}$ & $-0.04 \mathrm{~ns}$ & $0.08 \mathrm{~ns}$ & $0.03 \mathrm{~ns}$ & $0.18 \mathrm{~ns}$ & $-0.05 \mathrm{~ns}$ \\
\hline \multirow[t]{4}{*}{ PT2 } & RW & $0.41^{*}$ & $0.17 \mathrm{~ns}$ & $0.27 \mathrm{~ns}$ & $0.29 \mathrm{~ns}$ & $0.22 \mathrm{~ns}$ & $0.26 \mathrm{~ns}$ & $0.32 \mathrm{~ns}$ & $0.38^{*}$ \\
\hline & $\mathrm{RD}$ & $-0.45^{*}$ & $0.48^{* *}$ & $0.32 \mathrm{~ns}$ & $-0.17 \mathrm{~ns}$ & $-0.23 \mathrm{~ns}$ & $-0.15 \mathrm{~ns}$ & $-0.11 \mathrm{~ns}$ & $-0.43^{*}$ \\
\hline & LWD & $0.05 \mathrm{~ns}$ & $0.50^{* * *}$ & $0.52^{* * *}$ & $-0.40^{*}$ & $-0.33 \mathrm{~ns}$ & $-0.08 \mathrm{~ns}$ & $-0.09 \mathrm{~ns}$ & $0.09 \mathrm{~ns}$ \\
\hline & EWD & $-0.58^{* * *}$ & $0.20 \mathrm{~ns}$ & $0.17 \mathrm{~ns}$ & $-0.15 \mathrm{~ns}$ & $-0.04 \mathrm{~ns}$ & $-0.02 \mathrm{~ns}$ & $-0.03 \mathrm{~ns}$ & $-0.57^{* * *}$ \\
\hline
\end{tabular}

No correlations for PT3 and PT4 were statistically significant due to lower degrees of freedom $(d f=13)$

$R W$ ring width, $L W$ latewood density, $E W D$ earlywood density, $R D$ ring density, $n s$ not significant

mature transition patterns to PT2, while PT3 and PT4 had also similar pattern in the juvenile wood (not shown). When intercept and slope variances were modelled separately, the family by cambial age effect $(\operatorname{spl}(\mathrm{CA}) \times F)$ is apparent, while the data did not allow estimation of year by family $(Y \times F)$ interactions for the variables (i.e. all the estimates were at zero boundary). However, the modelled cubic splines were used to determine (i.e. visualise) the transition from corewood to outerwood.

After the effect of cambial age was separated from the effect of calendar year, correlations of ring width and wood density with climate variables were examined. The correlations for PT1 and PT2 are given in Table 5; however, no correlations were statistically significant for PT3 and PT4, due to a lower number of degrees of freedom (i.e. $d f=23$ for $\mathrm{PT} 1$ and PT2 and $d f=13$ for PT3 and PT4). A positive correlation between rainfall and RW was observed (e.g. 0.38 and 0.41 in PT1 and PT2, respectively). Annual rainfall had a negative correlation with RD (e.g. -0.07 and -0.45 in PT1 and PT2, respectively). However, the PT2 site was much drier than other sites during growing season and summer, and at PT2, rainfall during growing season had positive relationship with RD and LWD. Correlations between temperature (annual, growing season and/or summer) and RW were inconsistent between the two sites, and correlations between temperature and $\mathrm{RD}$ appeared to be negative (i.e. between 0 and -0.40 ). Statistically significant correlations between LWD and rainfall were positive and with temperature negative (Table 5). Correlations between ring width and density and climate in previous years (i.e. 1 year lag) were similar in sign, but less in magnitude (not shown).

In trials PT1 and PT2, for cambial ages greater than 15 years, the effect of cambial age was diminished (Fig. 2). Under the assumption that cambial age has no effect, it was possible to isolate the random effect of year $(Y)$ in a repeated measures analyses of variance (Table 6).
For ring width and density at cambial ages greater than 15 years, a significant year by family interaction $(Y \times F)$ was found (Table 6 and Fig. 3).

Evidence was found that certain climate features in particular years are responsible for the $Y \times F$ interactions. For example, at PT2 site, the unusually high summer rainfall in 1987 and 1988 strongly affected the sum of rank changes for $\mathrm{RD}$ and RW, i.e. caused strong $Y \times F$ interactions. At PT1 site, the summer rainfall in 1986 was $310 \mathrm{~mm}$ which was almost twice the average summer rainfall from 1972 to 1997 of $156 \mathrm{~mm}$. At the same time, the average of family rank changes (i.e. absolute value ignoring the sign) for $\mathrm{RD}$ in 1987 was 5.2, while the average from 1988 to 1997 was 3.0. The difference in rank changes was statistically significant at $p=0.05$ level of significance (Table 7).

Overall, at PT1 site in Gippsland, Victoria, there was a significantly higher number of changes in absolute family ranks than at PT2 site in Green Triangle, South Australia (e.g. 7.5 vs. 2.5 for RW). PT1 had also a much higher

Table 6 Variance component estimates from repeated measures analysis of variance for year, family and year by family interaction and first-order autocorrelation for variables: ring width and density, latewood density and earlywood density, for cambial ages greater than 15

\begin{tabular}{llllll}
\hline & & RW & RD & LWD & EWD \\
\hline PT1 & $Y$ & $222^{* * *}$ & $1,143^{* * *}$ & $8,688^{* * *}$ & $4,401^{* * *}$ \\
& $F$ & $1.56^{* * *}$ & $5.66^{* * *}$ & $3.04^{* * *}$ & $4.63^{* * *}$ \\
& $Y \times F$ & $1.28^{* * *}$ & $1.184^{* * *}$ & $1.134^{* * *}$ & $1.143^{* * *}$ \\
& AR1 & $0.92^{* * *}$ & $0.79^{* * *}$ & $0.82^{* * *}$ & $0.82^{* * *}$ \\
PT2 & $Y$ & $402^{* * *}$ & $5,517^{* * *}$ & $8,274^{* * *}$ & $8,274^{* * *}$ \\
& $F$ & $3.79^{* * *}$ & $6.35^{* * *}$ & $2.49^{* * *}$ & $2.49^{* * *}$ \\
& $Y \times F$ & $1.10^{* * *}$ & $1.27^{* * *}$ & $1.17^{* * *}$ & $1.17^{* * *}$ \\
& AR1 & $0.85^{* * *}$ & $0.84^{* * *}$ & $0.77^{* * *}$ & $0.77^{* * *}$ \\
\hline
\end{tabular}

$Y$ year, $F$ family, $Y \times F$ year by family interaction, $A R 1$ first-order autocorrelation, $R W$ ring width, $R D$ ring density, $L W D$ latewood density, EWD earlywood density 
Fig. 3 Predicted values of ring width $(R W)$ and relative ring density $(R D)$ over years for 33 half-sib families at PT2, for cambial ages greater than 15 years
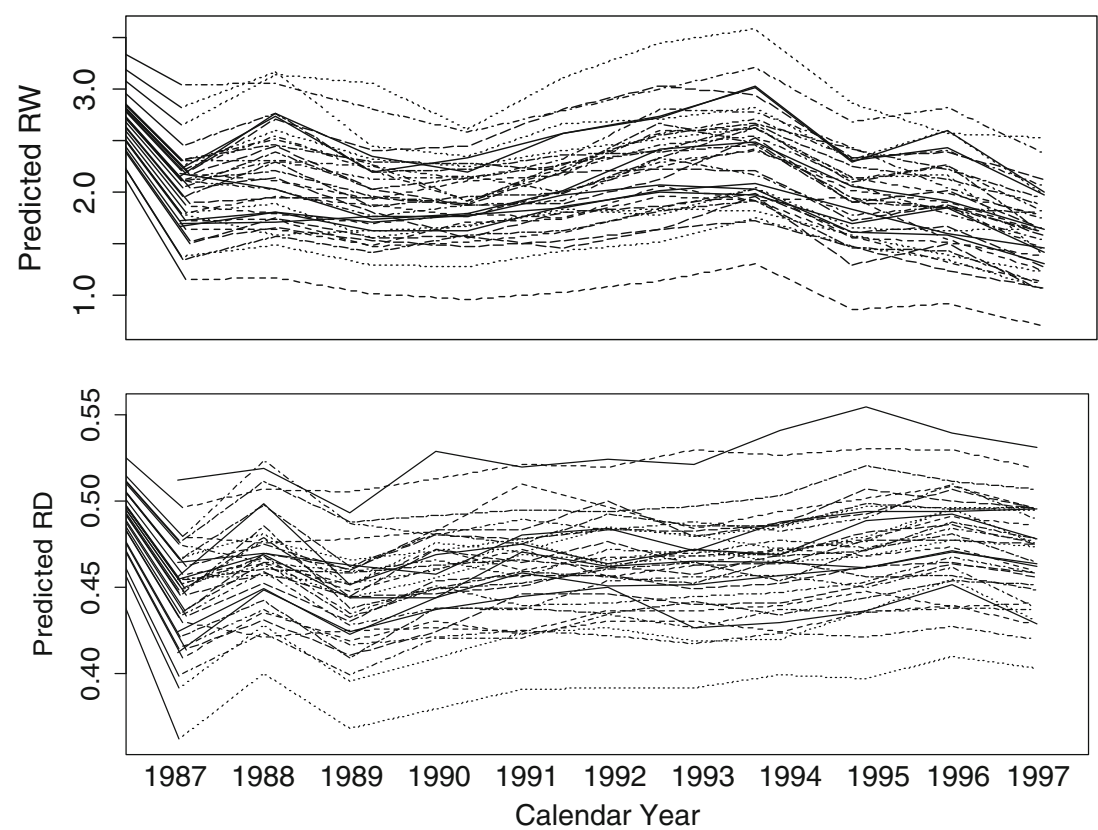

coefficient of variation for average summer rainfall than PT2 (i.e. $40 \%$ vs. $20 \%$ ). Among families, some were more interactive than others, and the maximum absolute rank changes over years for RW ranged between 7 and 20 at PT1 and between 0 and 14 at PT2. The family with 0 rank changes for RW at PT2 was consistently lowest ranked (Fig. 3). Rank changes and the interactions were generally more pronounced for RW than for RD.

\section{Discussion}

\subsection{Cambial age interacted with family effects}

The effect of cambial age on tree ring properties is not well understood because the effect interacts with factors such as silvicultural management, geographic location and/or site (e.g. Guller et al. 2012). In previous studies in Australia, significant differences were found among families in ring width and ring area-weighted wood density ( $\mathrm{Li}$ and $\mathrm{Wu} \mathrm{2005}$; Gapare et al. 2006, 2012). In this study, using the same data sets, for the profiles of RW, RD, LWD and EWD, cambial age (i.e. ontogeny) explained the highest proportion of the ring-to-ring variation. Furthermore, family by cambial age (i.e. cubic spline parameters) explained a smaller, but significant, proportion of the variation. Significant genotype by cambial age and site by cambial age interaction for ring density profiles was found in other conifers (e.g. Ivković and Rozenberg 2004).

\subsection{Climate affected growth and wood characteristics}

In radiata pine in Australia, and conifers more generally, rainfall is positively correlated with growth (e.g. Fritts et al. 1999; Battaglia et al. 2009), but fast growth often negatively correlates with wood density (e.g. Ivković et al. 2009). However, two progeny trial sites described here differ in climate: PT2 has Mediterranean, while PT1 temperate type of climate. The PT2 site had a significantly lower rainfall, especially during growing season and summer. Unlike PT1, PT2 had positive correlation of RD and LWD with rainfall during growing season and summer. On the other hand, correlations between temperature during growing season and $\mathrm{RD}$ appeared to be generally negative, but not significant. Conversely, in boreal climate, for example, the correlations of summer mean temperature and degree days with RD can be positive and significant (Peltola et al. 2009).

Table 7 Average rank changes for 33 families in two progeny trials PT1 and PT2, between 1987 and 1998 for variables: ring width and density

\begin{tabular}{lllllllllllllllll}
\hline & & 87 & 88 & 89 & 90 & 91 & 92 & 93 & 94 & 95 & 96 & 97 & 98 & Overall \\
\hline PT1 & RW & 7.9 & 7.8 & 8.2 & 7.6 & 7.4 & 7 & 7.9 & 6.9 & 7.6 & 7.7 & 7.3 & 6.4 & 7.5 \\
& RD & 5.2 & 3.6 & 3.2 & 2.1 & 2.5 & 2.4 & 2.9 & 2.6 & 2.7 & 3.8 & 4.5 & N/A & 3.2 \\
PT2 & RW & N/A & N/A & 3.8 & 2.6 & 2.4 & 2.6 & 1.8 & 2.1 & 2.2 & 2.6 & 2.6 & 2.7 & 2.5 \\
& RW & 2.6 & 3.7 & 1.9 & 2 & 2.7 & 1.9 & 1.8 & 2.1 & 1.8 & 1.8 & 2.3 & N/A & 2.2 \\
\hline
\end{tabular}

$R W$ ring width, $R D$ ring density 


\subsection{Calendar year interacted with family effects}

For growth rings older than 15 years, the effect of cambial age diminished, and the effect of year could be examined independently from cambial age effects. A significant year by family interaction was found. There was strong evidence that certain climate features (e.g. summer rainfall) in particular years were responsible for year by family interactions at the PT2 site in South Australia. At the same time, the progeny trial PT1 in Victoria had higher family by year interactions and also more variation for average summer rainfall then the PT2 site. Such climate features can be used together with climate change scenarios to predict how different genotypes may respond to climate change (e.g. Rozenberg et al. 2004).

\subsection{Implications for genetic selection}

This research study had a limited scope and provided only preliminary answers to the question of genotype by year interactions. However, by further studies of the patterns of variation in wood properties, we will gain insight into causeand-effect relationships between climate and wood variability (e.g. Downes and Drew 2008). Significant progress has already been made in use of ring-to-ring and within ring data to evaluate the effects of climate change, such as hotter summers, drier winters and/or higher $\mathrm{CO}_{2}$ on tree growth and mortality (Rozenberg et al. 2004; Dalla-Salda et al. 2009; Booth et al. 2010).

Radiata pine in Australia originates from two provenances on Californian mainland, which are both characterised by a Mediterranean-type, winter-rainfall climate (for details see Gapare et al. 2012). It is also unlikely that there was much local adaptation since the species' introduction. Nevertheless, differential response to climate (i.e. plasticity) was observed between genotypes. Exploring how different genotypes react to climate may prove useful in the future. For example, a genotype that does not respond favourably to drought periods may be eliminated from the breeding programme. On the other hand, if certain genotypes (individual parents, families or clones) perform better under certain climatic conditions that are expected to prevail in the future, they can be deployed or infused in the breeding population.

\footnotetext{
Acknowledgments Thanks to $\mathrm{Li} \mathrm{Li}$ and Aljoy Abarquez who processed samples and produced data sets used in this study. Thanks also to Leopoldo Sanchez, Jean-Charles Bastien, Luc Paques and Frederic Millier of INRA, Orléans, France for their time spent in discussions with the senior author. Data sets used in this study originate from two projects funded by Forest and Wood Products Australia. The senior author's visit to INRA, France and this research were funded by the 2010 Fellowship from J.W. Gottstein Memorial Trust.
}

\section{References}

Apiolaza LA (2009) Modeling wood quality using random regression splines. Australasian Forest Genetics Conference. 20-22 April, Perth, Western Australia, Australia. http://apiolaza.net/ publications.html Accessed 1 June 2012

Apiolaza LA, Garrick DJ (2001) Analysis of longitudinal data from progeny tests: some multivariate approaches. For Sci 47:129-140

Battaglia M, Bruce J, Brack C, Baker T (2009) Climate change and Australia's plantation estate: analysis of vulnerability and preliminary investigation of adaptation options. Forest \& Wood Products Australia Ltd. Melbourne

Booth TH, Kirschbaum MUF, Battaglia M, Stokes C, Howden M (2010) Adapting agriculture to climate change: preparing Australian agriculture, forestry and fisheries for the future. CSIRO, Melbourne, pp 137-152

Butler D, Cullis BR, Gilmour AR, Gogel BJ (2009) ASReml-R reference manual. Release 3.00. Department of Primary Industries and Fisheries, Queensland

Chen PY, Welsh C, Hamann A (2010) Geographic variation in growth response of Douglas-fir to interannual climate variability and projected climate change. Glob Chang Biol 16:3374-3385

CSIRO (2001) Climate change projections for Australia. www.dar.csiro.au/publications/projections2001.pdf. Accessed 1 Sept 2010

Dalla-Salda G, Martinez-Meier A, Cochard H, Rozenberg P (2009) Variation of wood density and hydraulic properties of douglas-fir (Pseudotsuga menziesii (mirb.) franco) clones related to a heat and drought wave in France. For Ecol Manag 257:182-189

De Martonne E (1926) L'indice d'aridite. Comptes Rengues de l'Academie des Sciences, Paris

R Development Core Team (2012) R: a language and environment for statistical computing, R Foundation for Statistical Computing, Vienna, Austria

Downes GM, Drew DM (2008) Climate and growth influences on wood formation and utilisation. South For 70:155-167

Downes GM, Drew D, Battaglia M, Schulze D (2009) Measuring and modelling stem growth and wood formation: an overview. Dendrochronol 27:147-157

Evans R, Ilic J (2001) Rapid prediction of wood stiffness from microfibril angle and density. For Prod J 51:53-57

Fritts HC (1976) Tree rings and climate. Academic, New York

Fritts HC, Shashkin AS, Downes GM (1999) TreeRing 3: a simulation model of conifer ring growth and cell structure. In: Wimmer R, Vetter RE (eds) Tree ring analysis: biological, methodological and environmental aspects. $\mathrm{CAB}$ International, Wallingford, pp 3-32

Gapare WJ, Wu HX, Abarquez A (2006) Genetic control in the time of transition from juvenile wood to mature wood in Pinus radiata D. Don. Ann For Sci 63:871-878

Gapare WJ, Ivković M, Dillon SK, Chen F, Evans R, Wu HX (2012) Genetic parameters and provenance variation of Pinus radiata $\mathrm{D}$. Don. 'Eldridge collection' in Australia 2: wood properties. Tree Genet Genomes 8:895-910

Guller B, Isik K, Cetinay S (2012) Variations in the radial growth and wood density components in relation to cambial age in 30-yearold Pinus brutia Ten. at two test sites. Trees 26:975-986

Harrell FE (2001) Regression modeling strategies with applications to linear models, logistic regression, and survival analysis. Springer, Heidelberg, Springer Series in Statistics

Inc RI (2001) WinDendro and WinCell user manuals. Regent Instruments Inc., Québec

Ivković M, Rozenberg P (2004) Description and modelling of withinring wood density in clones of three coniferous species. Ann For Sci 61:759-769 
Ivković M, Gapare WJ, Abarquez A, Ilic J, Powell MB, Wu HX (2009) Prediction of wood stiffness, strength, and shrinkage in juvenile wood of radiata pine. Wood Sci Tech 43:237-257

Li L, Wu HX (2005) Efficiency of early selection for rotation-aged growth and wood density traits in Pinus radiata. Can J For Res 35:2019-2029

Littell RC, Milliken GA, Stroup WW, Wolfinger R (1996) SAS system for mixed models. SAS Institute Inc, Cary

Martinez-Meier A et al (2008) Genetic control of the tree-ring response of Douglas-fir (Pseudotsuga menziesii (Mirb.) Franco) to the 2003 drought and heat-wave in France. Ann For Sci 65:102

Martinez-Meier A, Sanchez L, Dalla-Salda G, Gallo L, Pastorino M, Rozenberg P (2009) Ring density record of phenotypic plasticity and adaptation to drought in Douglas-fir. For Ecol Manag 258:860-867
McLane SC, LeMay VM, Aitken SN (2011) Modeling lodgepole pine radial growth relative to climate and genetics using universal growth-trend response functions. Ecol Appl 21:776-788

Peltola H, Gort J, Pulkkinen P, Gerendiain AZ, Karppinen J, Ikonen VP (2009) Differences in growth and wood density traits in Scots pine (Pinus sylvestris L.) genetic entries grown at different spacing and sites. Silva Fenn 43:339-354

Rozenberg P, Franc A, Bastien C (2001) Improving models of wood density by including genetic effects: a case study in Douglas-fir. Ann For Sci 58:385-394

Rozenberg P, Schüte G, Ivkovich M, Bastien C, Bastien JC (2004) Clonal variation of indirect cambium reaction to within-growing season temperature changes in Douglas-fir. For (Oxford) 77:257-268

Verbyla AP, Cullis BR, Kenward MG, Welham SJ (1999) The analysis of designed experiments and longitudinal data by using smoothing splines (with discussion). App Stat 48:269-311 